\title{
ANALISIS PESAN MORAL DALAM LEGENDA MON SEURIBÈE DI GAMPÔNG PARANG IX, KECAMATAN MATANGKULI, KABUPATEN ACEH UTARA
}

\author{
oleh \\ Muhammad Aidil Akbar, Radhiah*, Safriandi \\ *Dosen Program Studi Pendidikan Bahasa Indonesia, Universitas Malikussaleh \\ Surel: radhiah@unimal.ac.id
}

\begin{abstract}
ABSTRAK
Penelitian ini bertujuan untuk mendeskripsikan jenis pesan moral dalam legenda Mon Seuribèe di Kecamatan Matangkuli, Kabupaten Aceh Utara dan mendeskripsikan bentuk penyampaian pesan moral dalam legenda Mon Seuribèe Kecamatan Matangkuli, Kabupaten Aceh Utara. Metode penelitian yang digunakan dalam penelitian ini adalah metode deskriptif kualitatif. Teknik pengumpulan data dilakukan dengan cara teknik rekam dan catat. Teknik ini dilakukan dengan mengobservasi dan mewawancarai narasumber di Gampông Parang IX, Kecamatan Matangkuli terkait kisah legenda Mon Seuribèe. Hasil penelitian menunjukkan jenis dan wujud pesan moral, yaitu: 1) hubungan manusia dan Tuhannya dalam wujud beriman dan berdoa. 2) hubungan manusia dan dirinya sendiri dalam wujud kejujuran, bertanggung jawab, kemandirian, kerendahan hati. 3) Hubungan manusia dan manusia lain dalam wujud kekeluargaan, kerukunana, tolong-menolong, menghargai dan menghormati. Hasil penelitian selanjutnya yaitu, Bentuk penyampaian pesan moral secara langsung dilihat melalui uraian pengarang dan melalui tokoh, selanjutnya bentuk penyampaian secara tidak langsung dilihat dari peristiwa dan konflik.
\end{abstract}

Kata Kunci: legenda, pesan, moral. 


\section{PENDAHULUAN}

Masyarakat Aceh banyak memiliki keanekaragaman sastra daerah yang kini hampir punah, salah satunya cerita rakyat atau legenda. Cerita rakyat atau legenda adalah beberapa bagian dari tradisi lisan yang hidup dalam masyarakat Aceh, sebagai hasil budaya, cerita rakyat atau legenda tersebut memiliki fungsi sebagai pengungkapan alam pikiran, sikap dan nilai-nilai kehidupan yang sangat bermanfaat bagi masyarakat setempat. Lebih dari itu, kenyataan dalam masyarakat bahwa nilai dan tradisi yang terdapat dalam tradisi lisan yang hidup di sana mulai ditinggalkan. Pada umumnya, legenda dapat mengisahkan mengenai suatu kejadian di suatu tempat atau asal muasal suatu tempat. Tokoh-tokoh yang dimunculkan dalam legenda umumnya mempunyai kekuatan yang luar biasa, seperti mampu terbang, mempunyai burung yang dapat ditunggangi atau hewan-hewan yang tidak ada pada zaman sekarang, sepeti halnya legenda (Putro Neng, Asai Mula Gampông Parang IX, Asai Mula Mon Seuribèe, dan lain-lain) dalam kedudukannya sebagai sastra daerah mengandung nilai-nilai pendidikan dan nilai moral yang sangat bermanfaat bagi kehidupan masyarakat. Selain itu, kisah yang terkandung dalam legenda biasanya akan menjadi sejarah yang dimiliki tiap-tiap daerah.

Pembahasan mengenai legenda juga biasa disebut sebagai suatu saran yang berhubungan dengan ajaran moral tertentu yang bersifat praktis, yang dapat diambil (ditafsirkan) lewat cerita yang bersangkutan oleh pembaca. Pesan moral dalam legenda merupakan suatu tolak ukur untuk menentukan baik atau buruknya sikap dan sifat serta tindakan manusia. Hal tersebut dapat dilihat dari berbagai segi seperti berdasarkan pandangan hidup suatu masyarakat, yaitu tingkah laku yang sesuai dengan kesusilaan, akhlak, dan budi pekerti dengan demikian, legenda wajib mengandung pesan moral sebagai ajaran, introspeksi, dan refleksi diri.

Legenda, sebagaimana karya sastra lainnya juga memiliki pesan moral. Nurgiyantoro (2013:430) mengemukakan bahwa pesan moral dalam karya sastra terangkum dalam tema, karakter dan unsur lain yang membentuk suatu karya sastra. Pesan moral penting disampaikan kepada penikmat atau pembaca karya sastra. Melalui pesan moral, pengarang atau karya sastra dapat menyampaikan sisi baik dan buruk tentang kehidupan. Ajaran moral dalam karya sastra dipandang sebagai amanat dan pesan. Unsur amanat merupakan gagasan yang mendasari penulisan atau penciptaan karya sastra itu sendiri.

Berdasarkan uraian tersebut, peneliti akan mengkaji pesan moral dalam legenda Mon Seuribèe yang ada dalam masyarakat Matangkuli, Kabupaten Aceh Utara. Penelitian ini menarik untuk diteliti karena beberapa alasan, Pertama penelitian berkenaan dengan pesan moral tidak terlepas oleh ajaran atau pesan untuk manusia. Hal ini sesuai dengan pendapat yang dikemukakan oleh Nurgiyantoro (2013:429) moral adalah sesuatu yang disampaikan pengarang terhadap pembaca melalui karya-karyanya. Moral menunjuk pada pengertian (ajaran tentang) baik buruk yang diterima umum mengenai perbuatan, sikap, kewajiban, dan sebagainya; akhlak, budi pekerti, dan susila. Kedua, legenda mengenai Mon Seuribèe belum ada manuskrip. Ketiga, Penelitian ini dapat menjadi dokumentasi untuk semua kalangan, baik kelompok masyarakat maupun lembaga pemerintahan. Keempat, Legenda Mon Seuribèe belum populer pada kalangan masyarakat luas, termasuk di Provinsi Aceh sendiri karena belum adanya publikasi dalam bentuk buku atau dokumentasi lainnya. Cerita mengenai Mon Seuribèe masih milik komunitas masyarakat setempat karena tempat terjadi cerita Mon Seuribèe masih ada sampai saat ini dengan sumber akurat dari tokoh 
adat. Cerita Mon Seuribèe hanya berkembang di kalangan masyarakat setempat secara istana sentris.

\section{LANDASAN TEORI Pengertian Legenda}

Harun (2012:118) mengatakan bahwa legenda adalah cerita prosa rakyat yang dianggap benar-benar pernah terjadi oleh pemiliknya. Namun, cerita legenda tidak dianggap suci dan dapat terjadi pada setiap zaman. Lebih lanjut, Nurgiyantoro (2013:436) mengemukakan bahwa sejarah masa lalu menunjukkan karya sastra (cerita salah satunya legenda) banyak dipergunakan sebagai sarana untuk mengajarkan berbagai keperluan hidup. Memberikan ajaran moral, etika kehidupan, dan semangat perjuangan. Selain itu, legenda juga mewariskan pandangan hidup, nilai-nilai yang diyakini kebenarannya oleh masyarakat, serta mempertahankan eksistensi masyarakat (bangsa).

Selain itu, Hasanuddin (dalam Amin dkk, 2014:33) mengatakan bahwa legenda diambil dari istilah Inggris legend, yaitu cerita rakyat yang berisikan tentang tokoh, peristiwa, atau tempat tertentu yang mencampurkan fakta historis dengan mitos. Legenda dapat juga dikatakan sebagai sebuah cerita yang berhubungan dengan sejarah. Dengan demikian, legenda merupakan sebuah cerita yang menceritakan tentang tokoh serta peristiwa tertentu yang berkaitan dengan sejarah.

Sejalan dengan pendapat tersebut, Emeis (dalam Amin dkk, 2014:33) mengemukakan bahwa legenda merupakan bagian dari cerita rakyat yang dianggap pernah terjadi. Selain itu, ia menyebutkan bahwa cerita dalam legenda masih kuno dan setengahnya berdasarkan sejarah dan setengahnya lagi angan-angan.

Nurgiyantoro (dalam Hesti, 2018:2) mengemukakan bahwa legenda merupakan cerita magis yang sering dikaitkan dengan tokoh, peristiwa, dan tempat-tempat yang nyata sehingga legenda sering dianggap sebagai cerita historis, walaupun tidak didukung dengan fakta yang jelas. Legenda merupakan warisan budaya daerah yang sangat bernilai sehingga wajib dilestarikan. Salah satu kekayaan budaya seperti legenda didapatkan dari hasil pemikiran sistem sosial masyarakat. Peran penting legenda di sebuah daerah terletak pada kemampuannya mengkomunikasikan tradisi, pengetahuan, adat istiadat, atau menguraikan pengalaman-pengalaman manusia, baik dalam dimensi perseorangan maupun sosial. Legenda yang menjadi warisan pada masa lalu akan bermanfaat pada masa sekarang dan akan berguna pada masa yang akan datang, sehingga legenda suatu daerah perlu dikaji untuk melestarikan budaya setempat.

Berdasarkan pendapat tersebut dapat disimpulkan bahwa legenda adalah sebuah cerita yang dianggap pernah terjadi dalam kehidupan masyarakat yang berhubungan dengan sejarah. Legenda merupakan cerita yang bersifat magis yang sering dikaitkan dengan peristiwa dan tempat-tempat tertentu.

\section{Jenis-jenis Legenda}

Jan Harold Bruvand (dalam Harun, 2012:120) menggolongkan legenda ke dalam empat jenis, yaitu (1) legenda keagamaan (relegious legends), (2) legenda alam gaib (supernatural legends), (3) legenda perseorangan (personal legends), dan (4) legenda tempat ( local legends).

Harun (2012:120) mengatakan bahwa legenda keagamaan adalah legenda yang berhubungan dengan orang-orang saleh, seperti ulama dan umara. Para ulama yang menjadi legendaris biasanya adalah mereka yang keramat (karamah) atau memiliki kelebihan tertentu karena kedekatannya dengan Sang Khalik. Ulama semacam ini sangat dihormati, bahkan kuburannya pun selalu dimuliakan. Legenda alam gaib merupakan legenda yang berbentuk kisah yang dianggap benar-benar pernah terjadi dan pernah 
dialami oleh seseorang. Fungsi legenda ini adalah untuk meneguhkan kebenaran takhayul atau kepercayaan rakyat. Legenda alam gaib termasuk legendalegenda mengenai suatu tempat yang dianggap misteri, seperti pohon-pohon besar yang dianggap dikuasai oleh makhluk halus, cerita tentang makhluk halus, dan sebagainya. Legenda perseorangan adalah legenda mengenai tokoh-tokoh tertentu yang dianggap benar-benar pernah terjadi. Kelebihan yang dimiliki oleh tokoh-tokoh tersebut sebenarnya memang ada dalam setiap zaman. Pada awalnya, kejadian terkait dengan tokoh tersebut benar adanya. Namun, seiring dengan perjalanan masa, terkadang ada sebagian kejadian yang bergeser dari yang sebenarnya. Beberapa contoh mengenai legenda perseorangan, yaitu cerita Malem Diwa, Teungku Ibrahim Woyla, legenda Tapak Tuan (Teungku Lho' Tapa' Tuan), dan sebagainya. Selanjutnya, legenda tempat merupakan legenda yang berhubungan dengan cerita mengenai suatu tempat, nama tempat, dan bentuk topografi. Di Aceh banyak ditemukan nama tempat yang berhubungan dengan legenda, seperti nama Gunung Seulawah Agam, Seulawah Inöng, Bateè, Padang Tiji, Laweueng, Sabang/Pulau Weh, Sungai Mas, Paya Ni, Blang Bayeue Utang, dan sebagainya. Kebanyakan nama kampung di Aceh didasarkan pada kejadian atau nama benda tertentu.

\section{Pesan Moral dalam Karya Sastra}

Soyomukti

menjelaskan bahwa moral mengacu pada sejumlah ajaran dan khotbah tentang bagaimana manusia seharusnya hidup dan bertindak agar menjadi manusia yang baik dan mendukung terjadinya tatanan sosial yang dianggap baik. Pengertian moral dalam karya sastra itu sendiri berbeda dengan pengertian moral secara umum, yaitu menyangkut nilai baik buruk yang diterima secara umum dan berpangkal pada nilai-nilai kemanusiaan. Moral dalam karya sastra biasanya dimaksudkan sebagai petunjuk dan saran yang bersifat praktis bagi pembaca dalam kehidupan sehari-hari. Dalam hal ini, Nurgiyantoro (dalam Kurniasari, 2013:18) menyatakan bahwa moral pada cerita biasanya dimaksudkan sebagai suatu saran atau ajaran moral yang bersifat praktis dan dapat diambil atau ditafsirkan lewat cerita. Moral dalam cerita merupakan petunjuk yang sengaja diberikan oleh pengarang yang berhubungan dengan tingkah laku dan sopan santun dalam pergaulan.

Kenny (dalam Nugraha, 2014:42) mengatakan bahwa moral merupakan sesuatu yang ingin disampaikan oleh pengarang kepada pembaca. Moral sering juga disebut makna yang terkandung dalam sebuah karya atau makna yang disarankan lewat cerita. Adakalanya, moral diidentikkan pengertiannya dengan tema walau sebenarnya tidak selalu menyaran pada maksud yang sama. Karena keduanya merupakan sesuatu yang terkandung, dapat ditafsirkan, dan diambil dari cerita.

Lebih lanjut, Kenny (dalam Nugraha, 2014:43) mengemukakan bahwa moral dalam karya sastra biasanya dimaksudkan sebagai suatu saran yang berhubungan dengan ajaran moral tertentu yang bersifat praktis, yang dapat diambil (dan ditafsirkan), lewat cerita yang bersangkutan oleh pembaca. Ia merupakan "petunjuk" yang sengaja diberikan oleh pengarang tentang berbagai hal yang berhubungan dengan masalah kehidupan, seperti sikap, tingkah laku, dan sopan santun pergaulan. Ia bersifat praktis sebab "petunjuk" nyata, sebagaimana model yang ditampilkan dalam cerita itu lewat sikap dan tingkah laku tokoh-tokohnya.

Berdasarkan pendapat ahli tersebut dapat disimpulkan bahwa pesan moral adalah amanat atau ajak untuk berbuat baik. Pesan moral juga dapat menjadi tolak ukur seseorang sebagai alat introspeksi diri setelah membaca suatu karya sastra baik karya sastra modern maupun karya sastra tradisional. Hal 
tersebut selalu menjadikan karya sastra patut berada ditengah-tengah masyarakat agar setiap sesuatu yang terjadi menjadi penuntun kepada kebaikan, maka pada setiap karya sastra, pengarang selalu berusaha memberikan sesuatu yang bermanfaat bagi penikmatnya, salah satunya adalah pesan moral. Moral dalam karya sastra biasanya mencerminkan pandangan hidup pengarang yang bersangkutan, pandangannya tentang nilai-nilai kebenaran, dan hal itulah yang ingin disampaikannya kepada pembaca.

Nurgiyantoro (dalam Kurniasari, 2013:19 ) mengatakan bahwa karya fiksi yang mengandung nilai-nilai moral atau pesan moral, tentunya banyak sekali jenis dan wujudnya. Jenis moral dalam karya sastra sangat bervariasi dan tidak terbatas jumlahnya baik itu mengenai wujud hidup, maupun wujud yang menyangkut harkat dan martabat manusia yang dapat diangkat sebagai ajaran moral dalam karya sastra. Wujud hidup manusia itu dapat dibedakan ke dalam wujud Hubungan Manusia dan diri sendiri, Hubungan Manusia dan manusia lain dalam lingkup sosial termasuk hubungannya dengan lingkungan alam, dan Hubungan Manusia dan Tuhannya.

Perilaku Hubungan Manusia dan dirinya sendiri diklasifikasikan pada semua wujud ajaran moral yang berhubungan dengan individu sebagai pribadi yang menunjukkan akan eksistensi individu tersebut dengan berbagai sikap yang melekat pada dirinya. Nurgiyantoro (2013:324) memberikan contoh wujud pesan moral dalam hubungan dengan diri sendiri berupa menanyakan diri tentang suatu sikap masyarakat takut akan sesuatu dan dia berusaha untuk menghilangkan rasa takut pada dirinya sendiri. Pesan moral yang berhubungan dengan diri sendiri antara lain yang berhubungan dengan masalah-masalah diri pribadi, yaitu (1) kejujuran, (2) bertanggung jawab, (3) kemandirian, dan (4) kerendahan hati.
Putri (2016:22) menyatakan bahwa hubungan manusia dengan manusia lainnya atau dengan lingkungan merupakan hal yang sering dijumpai dalam karya sastra termasuk dalam cerita rakyat. Pesan moral yang berupa hubungan cinta kasih antara anak dan orang tua sering diceritakan dalam sebuah karya sastra. Perjuangan cinta kasih kepada orang tua adalah salah satu wujud yang sering dipamerkan dalam cerita rakyat seperti Malin Kundang dan sebagainya.

Selanjutnya, Nurgiyantoro (dalam Kumalasari, 2018:36) mengatakan bahwa agama lebih menunjukkan pada kelembagaan kebaktian kepada Tuhan dengan hukum-hukum yang resmi. Dalam Hubungan Manusia dan Tuhannya, manusia lebih banyak melakukan hal yang berhubungan dengan ibadah kepada Tuhannya. Religiositas melihat aspek yang di lubuk hati, riak getaran nurani pribadi, totalitas kedalam pribadi manusia.

\section{Bentuk Penyampaian Pesan Moral}

Nurgiyantoro (dalam Nugraha, 2014:45) mengatakan bahwa bentuk penyampaian moral dalam cerita fiksi dapat dibedakan ke dalam cara. Pertama, penyampaian pesan moral secara langsung, sedang kedua penyampaian secara tidak langsung.

\section{1) Bentuk Penyampaian Secara Langsung \\ Nurgiyantoro (dalam Nugraha,} 2014:46) mengatakan bahwa bentuk penyampaian pesan moral yang bersifat langsung, boleh dikatakan, identik dengan cara pelukisan watak tokoh yang bersifat uraian, telling, atau penjelasan, expository. Dilihat dari segi kebutuhan pengarang yang ingin menyampaikan sesuatu kepada pembaca, teknik penyampaian langsung tersebut komunikatif artinya, pembaca memang secara mudah dapat memahami apa yang dimaksudkan.

Lebih lanjut, Nurgiyantoro (dalam Nugraha, 2014:46) mengatakan bahwa 
bentuk penyampaian secara langsung dapat dilakukan dengan cara pelukisan sifat tokoh yang ada dalam karya sastra tersebut. Penggunaan sifat atau karakter tokoh akan diwujudkan/dibentukan dalam aktivitas tokoh sebagai alat untuk menyampaikan nilai moral. Bentuk ini secara langsung dapat dilihat pesan moralnya. Pembaca bisa langsung mengetahui pesan morang yang disampaikan oleh pengarang. Bentuk ini sangat disukai oleh pembaca awam yang lebih cenderung menjadikan karya sastra sebagai hiburan.

Pesan moral secara langsung biasanya terasa dipaksakan dan kurang koherensif dengan berbagai unsur yang lain. Keadaan tersebut justru akan mengurangi nilai literer karya yang bersangkutan. Hubungan komunikasi yang terjadi antara pengirim (addresser) dan pembaca (addresse) pada penyampaian pesan dengan cara ini adalah hubungan langsung.

2) Bentuk Penyampaian Secara Tidak Langsung

Nurgiyantoro (dalam Nugraha, 2014:46) mengatakan bahwa jika dibandingkan dengan bentuk sebelumnya, bentuk penyampaian pesan moral di sini bersifat tidak langsung. Pesan itu hanya tersirat dalam cerita, berpadu secara koherensif dengan unsur-unsur cerita yang lain. Walau betul pengarang ingin menawarkan dan menyampaikan sesuatu, ia tidak melakukannya secara serta-merta dan vulgar karena ia sadar telah memilih jalur cerita. Dilihat dari kebutuhan pengarang yang ingin menyampaikan pesan dan pandangannya itu, cara ini mungkin kurang komunikatif. Artinya pembaca belum tentu dapat menangkap apa sesungguhnya yang dimaksudkan pengarang, paling tidak kemungkinan terjadinya kesalahan tafsiran berpeluang besar.

Selanjutnya, Nugraha (2014:46) menyatakan bahwa kajian aspek moral dalam sastra, fiksi pada khususnya, banyak dilakukan untuk keperluan pembelajaran sastra disekolah, yaitu dalam rangka pemilihan bahan ajar yang sesuai. Secara faktual jumlah karya sastra dalam berbagai genre sangat banyak, tetapi belum tentu semuanya sesuai dengan kebutuhan peserta didik, khususnya yang terkait dengan muatan makna. Muatan makna yang baik untuk diajarkan adalah yang mengandung unsur moral yang sesuai dengan perkembangan kognitif peserta didik atau yang menjadi fokus pembelajaran. Hal itu juga terkait dengan tuntutan pendidikan karakter yang kini menjadi perhatian penuh berbagai pihak, tidak sekadar lagi sebagai wacana, untuk dilaksanakan di sekolah lewat berbagai mata pelajaran. Karya sastra dipandang sebagai salah satu sarana yang strategis untuk mencapai tujuan tersebut karena sastra mengandung dan menawarkan model-model kehidupan yang diidealkan serta sekaligus merupakan budaya dalam tidak yang semuanya disampaikan dengan cara-cara yang menyenangkan.

Berangkat dari sifat esensi inilah sastra tampil dengan kompleksitas makna yang dikandungnya. Hal tersebut justru dapat dipandang sebagai kelebihan karya sastra, kelebihan dalam hal banyaknya kemungkinan penafsiran, dari orang seorang dan dari waktu ke waktu. Hal ini pula yang menyebabkan karya sastra sering tidak ketinggalan, sanggup melewati batas waktu dan kebangsaan. Hubungan terjadi antara pengarang dan pembaca adalah hubungan yang tidak langsung dan tersirat. Kurang ada potensi pengarang untuk secara langsung menggurui pembaca sebab yang demikian justru tidak efektif di samping juga merendahkan kadar literer karya yang bersangkutan.

\section{METODE PENELITIAN}

Pendekatan penelitian ini adalah pendekatan deskriptif kualitatif. Pendekatan tersebut dilakukan dengan maksud membuat deskripsi, gambaran, atau lukisan secara sistematis. Menurut 
Creswell (2010:4) penelitian kualitatif merupakan metode-metode untuk mengeksplorasi dan memahami makna yang oleh sejumlah individu atau sekelompok orang berasal dari masalah sosial atau kemanusiaan. Jenis penelitian ini dipilih oleh peneliti karena penelitian ini mendeskripsikan secara sistematis dan cermat tentang pesan moral dalam legenda Mon Seuribèe.

Data adalah catatan atas kumpulan fakta. Data penelitian ini adalah pesan moral dalam legenda Mon Seuribèe. Arikunto (2010:172) mengatakan bahwa sumber data penelitian adalah subjek dari mana data diperoleh. Sumber data dalam penelitian adalah teks legenda Mon Seuribèe di Kecamatan Matangkuli, buku, jurnal dan beberapa hal lainnya yang berkenaan dengan pesan moral. Menurut Arikunto (2016:172), sumber data dalam penelitian merupakan subjek dari mana data tersebut diperoleh oleh peneliti. Hal ini sejalan dengan perincian sebagai berikut.

\section{1) Data Primer}

Sumber data primer adalah sumber utama dalam penelitan diperoleh dari hasil wawancara dengan narasumber tanpa adanya proses perantara. Adapun sumber data yang digunakan berupa teks legenda Mon Seuribèe di Kecamatan Matangkuli. Cerita atau teks tersebut diperoleh oleh peneliti secara langsung dari tokoh adat di Gampông Parang IX, Kecamatan Matangkuli.

\section{2) Data Sekunder}

Sumber data sekunder adalah data yang lebih dahulu dikumpulkan pihak luar penelitian, walaupun yang dikumpulkan merupakan data yang asli. Sumber data sekunder dalam penelitian ini adalah buku, jurnal, skripsi dan tesis yang mempunyai relevansi untuk memperkuat argumentasi dan melengkapi hasil penelitian ini.

Peneliti menggunakan teknik rekam dan catat. Teknik ini dilakukan dengan cara melakukan observasi dan mewawancarai narasumber di Gampông
Parang IX, Kecamatan Matangkuli. Wawancara dilakukan menggunakan alat rekam, seperti video dan alat rekam suara. Selanjutnya, hasil wawancara disalin ulang oleh peneliti sebagai data penelitian. Berikut ini tahapan yang dilakukan peneliti dalam proses pengumpulan data.

1) Merekam cerita rakyat dari tokoh adat.

Peneliti merekam cerita rakyat Mon Seuribèe berbahasa Aceh yang berasal dari Kecamatan Matangkuli.

2) Mengidentifikasi kalimat.

Peneliti kemudian memberikan tanda yang terdapat dalam teks yang telah dicatat kembali oleh peneliti pada kalimatkalimat yang mengandung pesan moral dalam cerita rakyat tersebut.

Teknik analisis data kualitatif bersifat induktif, yaitu analisis yang digunakan harus berdasarkan data yang diperoleh, selanjtnya dikembangkan dengan cara dideskripsikan (Sugiyono, 2017:130). Data-data ini diperoleh dengan menggunakan data primer dan data sekunder. Adapun langkah-langkah penelitian ini meliputi hal-hal sebagai berikut.

1) Menyeleksi Data

2) Klasifikasi Data

3) Penyajian Data

4) Menyimpulkan

\section{HASIL DAN PEMBAHASAN}

Berkaitan dengan rumusan
masalah, hasil penelitian ini mendeskripsikan jenis pesan moral dan bentuk penyampaian jenis pesan moral dalam legenda Mon Seuribèe di Kecamatan Matangkuli, Kabupaten Aceh Utara.

1) Jenis Pesan Moral dalam Legenda Mon Seuribèe di Kecamatan Matangkuli Kabupaten Aceh Utara

a) Hubungan Manusia dan Tuhannya Terdapat tiga belas data jenis pesan moral hubungan antara manusia dan Tuhannya. Jenis pesan moral Hubungan Manusia dan Tuhannya dengan wujud ketakwaan terdapat tujuh data, keikhlasan 
terdapat dua data. Tawakal terdapat empat data. Berikut paparan satu data di setiap poinnya.

(a) Ketakwaan dan Ketaatan

"Tunaikan saja apa yang ada dalam mimpi Abang. Mungkin itu suatu petunjuk yang bisa menyelesaikan permasalahan ini." ucap adik Teungku Batèe Putéh.

Kutipan di atas menggambarkan ketakwaan Teungku Batèe Putéh kepada Allah subhanahu wata'ala. Dalam kutipan tersebut yang dimaksud dengan mimpi Teungku Batèe Putéh adalah petunjuk yang disampaikan Allah melalui mimpi. Hal tersebut terjadi karena Teungku Batèe Putéh sangat yakin bahwa Allah akan menolongnya dan akan memberinya jalan keluar.

Berdasarkan kutipan tersebut pesan moral yang dapat dipetik adalah kualitas iman seseorang akan terlihat dari hubungannya dan Tuhannya. Cara dia menaati perintah Tuhan dan meninggalkan segala larangan-Nya termasuk juga cara dia dalam menghadapi atau menyelesaikan ujian dari Allah subhanahu wata'ala. Mukmin yang beriman selalu tenang dalam menghadapi masalah dan selalu tahu batasan-batasannya.

(b) Keikhlasan

Teungku Batèe Putéh tak bisa mengembalikan keadaan, Beliau berusaha ikhlas dengan semuanya. Teungku Batèe Putéh memeluk jasad istrinya sambil terisak tangis.

Kutipan di atas menggambarkan kedekatan tokoh Teungku Batèe Putéh dengan Allah subhanahu wata'ala. Hal tersebut dibuktikan dalam kutipan bahwa Teungku Batèe Putéh berusaha ikhlas menerima takdir yang Allah tentukan untuknya. Keikhlasan merupakan kesadaran agama yang memperlihatkan kedekatan hubungan seseorang dengan Tuhannya tanpa merasa putus asa dan berusaha untuk menerima segala ketentuan Allah subhanahu wata'ala.

Berdasarkan kutipan tersebut pesan moral yang dapat dikutip adalah manusia sebagai mukmin tidak boleh putus asa dan harus yakin kepada Allah subhanahu wa ta'ala. Segala ketetapan Allah subhanahu wata'ala baik berupa ujian, maupun berkah selalu harus disyukuri.

(c) Tawakal

Teungku Batèe Putéh tidak ingin segala usaha yang telah mereka lakukan itu sia-sia. Teungku Batèe Putéh memejamkan mata dan berharap diberi petunjuk langkah apa yang harus Beliau lakukan berikutnya. Rasa letihnya tak menjadi halangan untuk Beliau terus berusaha mencari apa yang harus Beliau lakukan selanjutnya.

Kutipan di atas menggambarkan rasa gundah yang dirasakan oleh Teungku Batèe Putéh. Dalam alkisah disebutkan bahwa Teungku Batèe Putéh pasrah atau berserah diri kepada Allah subhanahu wa ta'ala. Berdasarkan kutipan tersebut maksud dari berharap diberi petunjuk adalah harapan seorang hamba yang pasrah dengan segala ketentuan Allah.

b) Hubungan Manusia dan Dirinya Sendiri

Terdapat dua puluh lima data jenis pesan moral hubungan antara manusia dan dirinya sendiri. Kejujuran terdapat tiga data, bertanggung jawab terdapat sepuluh data, kemandirian terdapat lima data, dan kerendahan hati terdapat tujuh data. Berikut paparan satu data di setiap poinnya.

(a) Kejujuran

Di sisi lain, setelah Teungku Batèe Putéh kembali ke rumah, adiknya langsung menghampiri Beliau dan menanyakan perihal tombak yang telah dipinjami itu. Teungku Batèe Putéh berkata, "Tombakmu patah, saat aku menyerang gajah itu. Aku 
hanya menemukan gagang dari tombakmu, tapi ujungnya tertancap di paha gajah. Gajah itu lari hingga aku tak sempat mengambil kembali ujung tombakmu. Aku minta maaf."

Penggalan cerita tersebut menceritakan Teungku Batèe Putéh yang berkata jujur kepada adiknya bahwa tombak yang ia pinjam telah patah saat Teungku Batèe Putéh menyerang gajah yang masuk ke kebun miliknya. Teungku Batèe Putéh dengan jiwa besar merasa bersalah kepada adiknya harus mengatakan apa yang telah ia lakukan dengan sejujurnya. Kemudian, Teungku Batèe Putéh meminta maaf pada adiknya. Pesan moral yang terdapat pada kutipan tersebut adalah kejujuran sebagai jati diri Teungku Batèe Putéh.

(b) Bertanggungjawab

Tanpa pikir panjang Teungku Batèe Putéh menyuruh semua prajurit dan pelayan untuk istirahat sejenak. Tanpa ada yang menyadari ternyata tempat mereka berteduh adalah di bawah pohon bambu. Berhentilah mereka. Disandarkan Sang Putri di pangkuan sang Teungku dan mereka berdua pun tertidur pulas di bawah pohon bambu karena sangat merasa letih.

Kutipan di atas menceritakan bahwa Teungku Batèe Putéh yang harus memutuskan sesuatu saat di tengah perjalanan. Di tengah perjalanan, para rombongan tampak kelelahan dan Teungku Batèe Putéh memerintahkan kepada rombongannya untuk beristirahat. Berdasarkan analisis kutipan tersebut, Teungku Batèe Putéh memiliki moral yang bertanggung jawab, jenis pesan moral dalam kutipan cerita adalah Hubungan Manusia dan dirinya sendiri dengan wujud bertanggung jawab, yaitu yang menunjukkan peran tanggung jawab Teungku Batèe Putéh sebagai pemimpin yang harus mengambil keputusan dalam perjalanan.

(c) Kemandirian

Teungku Batèe Putéh memutuskan untuk mengintai gajah tersebut. Beliau pun berjaga-jaga di kebunnya pada malam hari. Dalam perjalanannya ke kebun, Teungku Batèe Putéh sudah bertekat kuat untuk menemukan jawaban. Bagaimanapun, Teungku Batèe Putéh sudah merasa kesal karena hasil tanamannya sudah sangat sering menjadi sasaran makhluk itu.

Analisis pada kutipan tersebut menceritakan tekad Teungku Batèe Putéh yang ingin menemukan jawaban pasti atas kejadian yang menimpanya. Teungku Batèe Putéh melakukan penjagaan di malam hari untuk mengintai kawanan gajah. Hal tersebut dilakukan karena Teungku Batèe Putéh merasa kesal terhadap kawanan gajah yang sering memakan tanaman milik Teungku Batèe Putéh dan warga. Berdasarkan kutipan tersebut jenis pesan moral adalah Hubungan Manusia dan dirinya sendiri dan wujud pesan moral kemandirian adalah penggambaran pekerjaan Teungku Batèe Putéh yang ingin menemukan jawaban pasti tentang tanaman miliknya yang menjadi sasaran para gajah.

(d) Kerendahan Hati

Putri terlihat tersenyum dengan wajah pucatnya yang menahan sakit. Putri merasa Teungku Batèe Putéh memang benar-benar laki-laki yang sangat menghargai wanita. Putri sangat terkesima dengan tutur kata dan sikap Beliau padanya.

Kutipan tersebut menceritakan putri raja yang merasa bahagia walau dalam keadaan sakit. Ia berbahagia karena tidak salah telah menerima Teungku Batèe Putéh sebagai suaminya. Dalam keadaan sakitnya itu, tuan putri yakin bahwa Teungku 
Batèe Putéh adalah sosok yang sangat menghargai wanita, bertutur kata baik, dan bersikap sopan santun. Sebagai putri seorang raja, seorang putri tidak pernah malu menikah dengan orang biasa seperti Teungku Batèe Putéh. Hal tersebut menunjukkan kerendahan hati seorang putri raja. Berdasarkan analisis kutipan teks tersebut jenis pesan moral adalah Hubungan Manusia dan dirinya sendiri dengan wujud kerendahan hati, yaitu penggambaran kerendahan hati putri raja yang bahagia bersama seorang rakyat biasa.

c) Hubungan Manusia dan Manusia Lain

Terdapat dua puluh lima data dari jenis pesan moral hubungan antara manusia dan manusia lain dengan wujud kekeluargaan, kerukunan, tolongmenolong, serta menghargai dan menghormati. Dari jumlah data tersebut, akan dijabarkan satu data setiap poinnya, yaitu sebagai berikut.

(a) Kekeluargaan

"Terima kasih telah sepenuhnya percaya dan yakin padaku. Aku sangat beruntung bisa menjadikanmu istriku. Aku akan bicara pada raja tentang niatku ini," ucap Teungku Batèe Putéh tersenyum lega karena bisa kembali ke kampung halamannya yang telah lama Beliau tinggalkan.

Gambaran pada kutipan di atas adalah Teungku Batèe Putéh yang bahagia dan bangga pada istrinya atas keputusan ingin kembali ke kampung halaman. Sikap saling percaya antara putri dan Teungku Batèe Putéh membuat jalinan rumah tangga tampak harmonis, keduanya saling mendukung, seperti pada kutipan di atas. Putri memosisikan dirinya sebagai seorang istri walaupun kasta putri jauh lebih tinggi daripada suaminya. Namun, dalam hal pernikahan Teungku Batèe Putéh tetaplah menjadi kepala keluarga sehingga putri sebagai istri ikut mendukung apapun niat dan langkah yang akan dilakukan suaminya. Berdasarkan analisis kutipan tersebut jenis pesan moral adalah Hubungan Manusia dan manusia lain dengan wujud kekeluargaan, yaitu dukungan putri raja sebagai seorang istri yang selalu mendukung suaminya.

(b) Kerukunan

Selang beberapa waktu setelah menikah, hamillah sang putri. Hal itu membuat Teungku Batèe Putéh berpikir bahwa saat inilah Beliau bisa beralasan untuk kembali ke kampung halamannya. Teungku Batèe Putéh membincangkan keinginannya pada sang istri.

Analisis yang dapat digambarkan pada kutipan di atas adalah keinginan Teungku Batèe Putéh untuk pulang ke kampung halaman. Niat Teungku Batèe Putéh dibincangkan agar sang istri tidak salah paham, apalagi menjadi marah. Berdasarkan kutipan tersebut jenis pesan moral dalam cerita Hubungan Manusia dan manusia lain dan wujud pesan moral adalah kerukunan, yaitu mempertahankan kerukunan dalam keluarga agar tidak terjadi perselisihan pada suatu masalah yang ingin diambil keputusan.

(c) Tolong-menolong

Teungku Batèe Putéh akhirnya harus meminjam tombak emas yang dimiliki adiknya. Setelah mendapatkan tombak, Teungku Batèe Putéh segera kembali ke kebun.

Analisis yang dapat digambarkan dalam kutipan tersebut adalah permintaan tolong Teungku Batèe Putéh pada adiknya untuk dipinjamkan tombak agar ia dapat menyerang gajah yang masuk ke kebun miliknya. Pada cerita tampak Teungku Batèe Putéh meminjam tombak emas milik adiknya, 
kemudian ia segera kembali ke kebun. Hal yang dilakukan oleh Teungku Batèe Putéh adalah meminta tolong pada adiknya dan adiknya bersedia menolong abangnya dengan meminjamkan tombaknya. Hal tersebut menunjukkan rasa tolongmenolong. Berdasarkan kutipan tersebut jenis pesan moral adalah Hubungan Manusia dan manusia lain dengan wujud tolong-menolong. Tidak hanya adiknya Teungku Batèe Putéh yang memiliki sikap tolongmenolong.

(d) Menghargai dan Menghormati "Maaf Tuanku Raja. Saya merasa lancang jika harus menyentuh putri begitu saja. Saya tidak kuasa melakukannya," tutur Teungku Batèe Putéh.

Berdasarkan kutipan tersebut Teungku Batèe Putéh sangat menghargai putri raja. Menurutnya, terlalu lancang apabila Teungku Batèe Putéh langsung menyentuh tuan putri yang lukanya terdapat pada bagian dalam paha tuan putri. Berdasarkan analisis, jenis pesan moral yang terdapat dalam kutipan tersebut adalah hubungan baik antara manusia dan manusia lainnya dengan wujud menghargai dan menghormati.

2) Bentuk Penyampaian Pesan Moral

a) Pesan Moral disampaikan Secara Langsung

Berdasarkan hasil penelitian dalam Cerita Legenda Mon Seuribèe di Gampông Parang IX, Kecamatan Matangkuli terdapat dua puluh empat data bentuk penyampaian nilai pesan moral secara langsung. Bentuk penyampaian nilai moral secara langsung melalui uraian pengarang terdapat Sembilan belas data dan bentuk penyampaian nilai moral secara langsung melalui tokoh terdapat lima belas data. Berikut contoh data yang didapat.

(a) Melalui Uraian Pengarang
Selang beberapa waktu setelah menikah, hamillah sang putri. Hal itu membuat Teungku Batèe Putéh berpikir bahwa saat inilah Beliau bisa beralasan untuk kembali ke kampung halamannya. Teungku Batèe Putéh membincangkan keinginannya pada sang istri.

Gajah jelmaan istrinya terlihat meneteskan air mata, beliau berjalan mendekat dan berisyarat untuk memberikan anak mereka. Karena merasa kasihan, Beliau menyerahkan anak mereka dan gajah itu memeluknya dengan belalainya. Rasa haru sang putri begitu dalam dan membuat Beliau menangis sejadijadinya. Teungku Batèe Putéh hanya menatap dan membiarkan istrinya melepaskan rindu pada anak mereka. Begitu erat gajah itu memeluk anak mereka dan tubuhnya terlihat begitu lemah hingga Beliau terduduk. Namun, terus memeluk anaknya.

Teungku Batèe Putéh mengusap air matanya dan bertekad untuk memakamkan istrinya secara layak. Teungku Batèe Putéh memberi kabar pada keluarganya untuk segera mepersiapkan pemakaman bagi istrinya.

Uraian pengarang dalam penggalan tersebut menggambarkan pesan moral kekeluargaan. Hubungan antara Teungku Batèe Putéh sebagai seorang suami yang sangat mencintai istri dan anaknya. Dalam penggalan tersebut, Teungku Batèe Putéh sedih karena tidak dapat berkumpul kembali sebagai keluarga yang utuh.

(b) Melalui Uraian Tokoh

"Terima kasih Ayah karena telah sangat memahami suamiku. Aku akan berjanji apa pun yang terjadi aku pasti selalu berada di sisinya dan mendampinginya." ucap sang Putri seraya tersenyum bahagia. 
Putri terlihat tersenyum dengan wajah pucatnya yang menahan sakit. Putri merasa Teungku Batèe Putéh memang benar-benar laki-laki yang sangat menghargai wanita. Putri sangat terkesima dengan tutur kata dan sikap Beliau padanya.

Pengarang menggambarkan pesan moral melalui tokoh Putri Meurah. Pesan moral yang disampaikan berupa hubungan kekeluargaan yang digambarkan oleh tokoh Putri Meurah sebagai seorang putri dari raja yang patuh dengan perkataan ayahnya dan sangat menyayangi serta dan menghormati ayahnya. Selanjutnya, pesan moral dengan wujud kekeluargaan, kerukunan dan menghormati suaminya yang disampaikan secara langsung melalui uraian tokoh putri Meurah sebagai seorang istri.

b) Pesan Moral disampaikan Secara Tidak Langsung

Terdapat dua puluh tujuh data bentuk penyampaian nilai pesan moral secara tidak langsung. Bentuk penyampaian nilai moral secara tidak langsung melalui peristiwa terdapat dua puluh data, dan bentuk penyampaian nilai moral secara langsung melalui konflik terdapat tujuh data.

(a) Melalui Peristiwa

Setelah melihat sekali lagi dan mengetahui dengan pasti letak ujung tombak yang menancap, Teungku Batèe Putéh menyadari bahwa dia tak bisa menyentuhnya.

Teungku Batèe Putéh dengan sangat hati-hati mencoba menarik perlahanlahan mata tombak itu. Akhirnya perlahan mata tombak itu bisa ditarik keluar oleh Teungku batèe putéh. Putri terlihat menahan rasa sakit dan perih dengan cucuran air mata membasahi pipinya. Teungku Batèe Putéh mengusap air mata istrinya dan menyuruh sang istri untuk istirahat agar lekas pulih dari sakitnya.
Peristiwa yang digambarkan pengarang dalam kutipan di atas adalah ketika Teungku Batèe Putéh menunaikan janjinya untuk menyembuhkan Putri Meurah dari lukanya. Pesan moral yang disampaikan secara tidak langsung oleh pengarang adalah kejujuran dan rasa tanggung jawab Teungku Batèe Putéh kepada Putri Meurah. Selanjutnya, pesan moral dengan wujud kekeluargaan digambarkan secara tidak langsung oleh pengarang melalui peristiwa tersebut.

(b) Melalui Konflik

Tekad Teungku Batèe Putéh begitu kuat untuk merebut anaknya kembali dan bisa segera membuat gajahgajah itu tidak mengganggu tanaman mereka lagi.

"Aku tidak melakukannya untuk diriku sendiri. Ini demi semua warga di sini. Tidakkah kalian merasa terganggu tanaman-tanaman di kebun terus menerus dimakan gajah itu," ucap Teungku Batèe Putéh meyakinkan warga.

Konflik dalam penggalan tersebut menggambarkan pesan moral hubungan manusia dan manusia lain dengan wujud tolong-menolong. Pesan moral tersebut disampaikan melalui konflik ketika Teungku Batèe Putéh bertekat untuk mengambil anaknya kembali dari gajah jelmaan istrinya dan mengajak warga unutk bekerja sama. Dalam konflik tersebut, Teungku Batèe Putéh tidak hanya bersiasat untuk mengambil anaknya. Namun, Teungku Batèe Putéh juga ingin menolong warga yang tanamannya juga dibabat oleh gajahgajah tersebut.

\section{PENUTUP}

Berdasarkan analisis yang telah dilakukan, maka kesimpulannya adalah sebagai berikut. 
1) Jenis pesan moral dalam legenda Mon Seuribèe Kecamatan Matangkuli, Kabupaten Aceh Utara adalah jenis pesan moral hubungan antara manusia dan tuhannya dengan wujud beriman dan berdoa terdapat empat data, jenis pesan moral hubungan antara manusia dengan dirinya sendiri dengan wujud kejujuran, bertanggung jawab, kemandirian, dan kerendahan hati terdapat dua puluh delapan data, jenis pesan moral hubungan antara manusia dengan manusia lain dengan wujud kekeluargaan, kerukunan, tolong-menolong, serta menghargai dan menghormati terdapat dua puluh lima data.

2) Bentuk penyampaian pesan moral dalam legenda Mon Seuribèe Kecamatan Matangkuli, Kabupaten Aceh Utara adalah bentuk penyampaian nilai pesan moral secara langsung melalui uraian pengarang dan tokoh terdapat empat data, dan bentuk penyampaian nilai pesan moral secara tidak langsung melalui peristiwa dan konflik terdapat empat data.

\section{DAFTAR PUSTAKA}

Amin, Irzal, Syahrul R, Ermanto. 2013. "Cerita Rakyat Penamaan Desa di Kerinci: Kategori dan Fungsi Sosial Teks". Jurnal Bahasa, Sastra, dan Pembelajaran, Vol. 1 Nomor 1. Hal. 31-41.

Arikunto, Suharsimi. 2010. Prosedur Penelitian: Suatu Pendekatan Praktik. Jakarta: Rineka Cipta.

Creswell, J. W. 2010. Research desaign: Pendekatan Kualitatif, Kuantitatif, dan Mixed. Yogyakarta: Pustaka Pelajar.

Harun, Mohd. 2012. Pengantar Sastra Aceh. Bandung: Citapustaka Media Perintis.
Hesti, Suci. 2018. "Kemampuan Siswa Kelas VII SMP Negeri 4 Banda Aceh Menceritakan Kembali Legenda Tuan Tapa dan Putri Naga". Skripsi. Banda Aceh: Universitas Syiah Kuala.

Kumalasari, Linda Putri. 2018. "Nilai Moral dalam Novel Selimut Mimpi Karya R. Adrelas Kemungkinannya sebagai Bahan Ajar SMA”. Skripsi. Semarang: Universitas Negeri Semarang.

Kurniasari, Gilar Ika. 2014. "Nilai Moral dalam Novel Rantau 1 Muara Karya Ahmad Fuadi dan Relevansinya sebagai Bahan Pembelajaran Sastra di Kelas XI SMA”. Skripsi. Pirworejo: Universitas Muhammadiyah Pirworejo.

Nugraha, Fajar Briyanta Hari. 2014. "Nilai Moral dalam Novel Pulang Karya Leila S Chudori”. Skrispi. Yogyakarta: Universitas Negeri Yogyakarta.

Nurgiyantoro. 2013. Teori Pengkajian Fiksi. Yogyakarta: Gajah Mada University Press.

Putri, Cut Eva Syamsoeddin. 2016. "Analisis Pesan Moral dalam Cerita Rakyat di Kecamatan Kuta Malaka". Skripsi. Banda Aceh: Universitas Syiah Kuala.

Sugiyono. 2010. Metode Penelitian Pendidikan. Bandung: Alfabeta. 